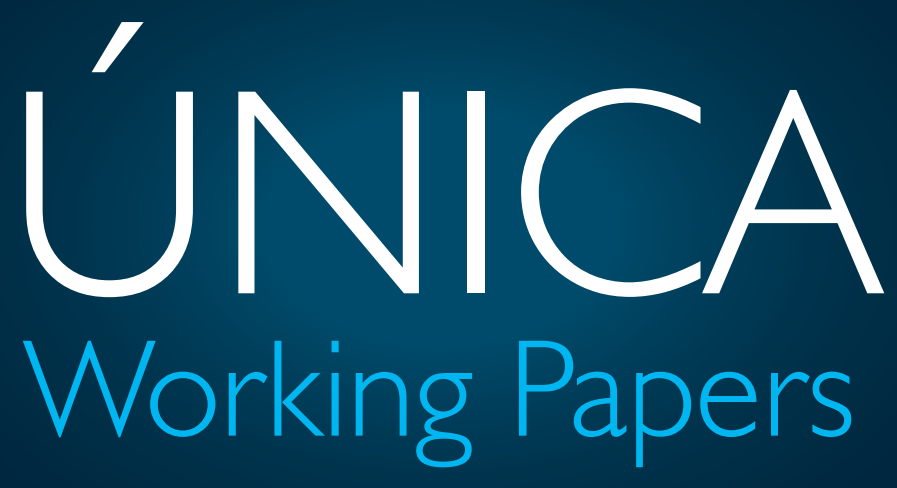

AUTHENTIC VIDEO MATERIALS, A TOOL FOR VOCABULARY LEARNING AND GLOBAL CITIZENSHIP SKILLS REFLECTION

- JASMIN ALFONSO VARGAS AND PAOLA XIMENA ROMERO MOLINA -

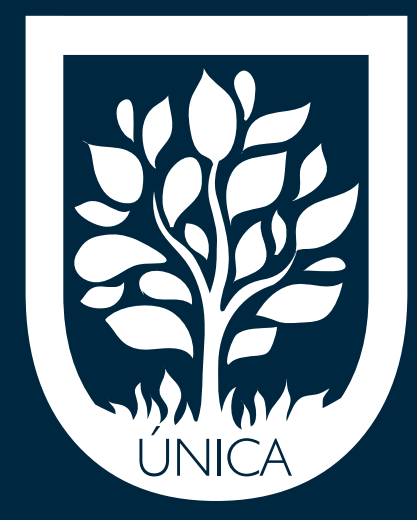

www.unica.edu.co 


\section{AUTHENTIC VIDEO MATERIALS, A TOOL FOR VOCABULARY LEARNING AND GLOBAL CITIZENSHIP SKILLS REFLECTION}

Jasmin Alfonso Vargas and Paola Ximena Romero Molina

Institución Universitaria Colombo Americana - ÚNICA, Bogotá, Colombia 
Facultad de Educación

Programa de Licenciatura en Bilingüismo con Énfasis en Español e Inglés

Bogotá D.C.

2019

Reg. SNIES: 106242

Vigilada MinEducación

Working Paper - Resultado de Investigación

Grupo de Investigación Innovation on Bilingual Education - INNOBED Categoría B Colciencias

Dirección de Investigaciones

Calle 19 No. $2^{\mathrm{a}}$-49, Piso 3

Centro Colombo Americano

Teléfono: 2811777 Ext. 1291

dir.investigaciones@unica.edu.co

$\underline{\text { www.unica.edu.co }}$

DOI: https://doi.org/10.26817/paper.06

Prohibida la reproducción parcial o total de esta obra sin autorización de la Institución Universitaria Colombo Americana - ÚNICA 


\section{Acknowledgements}

Institución Universitaria Colombo Americana - UNICA and her President María Lucía Casas

Pardo, M.A., for making this study possible.

Our students who inspired us to successfully carry out this project and whose invaluable contributions made its development possible.

We are immensely grateful to our reviewers Diego Boada, $\mathrm{PhD}$ and Fulbright Scholar and Kunti Adhikari, M.A., and Fulbright Scholar for the insightful comments that greatly helped us improve our manuscript.

Constanza Amezquita, PhD, Director of Research, Institución Universitaria Colombo Americana -UNICA for her guidance and support. 


\section{Authentic Video Materials, a Tool for Vocabulary Learning and Global Citizenship Skills Reflection}

\section{Authors}

Jasmin Alfonso Vargas and Paola Ximena Romero Molina

BA in Bilingual Education, Institución Universitaria Colombo Americana-UNICA, Bogota, Colombia

Jasmin Alfonso is a Fulbright scholar and Professor at Institucion Universitaria Colombo Americana (UNICA) in Bogota, holds a BA in Bilingual Education from Institucion Universitaria Colombo Americana and a MA in teaching English to Speakers of Other languages (TESOL) from Michigan State University (MSU). Teaching areas: English as a Foreign Language, Microteaching Basic Education, and Educational Administration.

Research areas: authentic materials, citizenship competencies, and educational leadership. Jasmin Alfonso Vargas jasmin.alfonso@unica.edu.co Av. 19 No 2-49

Bogota, Colombia

+571 2811777

P. Ximena Romero has an MA in TESOL from Michigan State University (MSU) and a BA in English Teaching from Universidad Nacional de Colombia. Currently, she is a Teacher-researcher at the BA in bilingual education at UNICA - Institución Universitaria Colombo Americana. Her areas of research interest are vocabulary learning and teaching, pronunciation teaching, use of authentic materials, and emotions and English learning.

Paola Ximena Romero Molina

ximena.romero@unica.edu.co

Av. 19 No 2-49

Bogota, Colombia

+571281 1777 


\title{
Authentic Video Materials, a tool for vocabulary learning and Global Citizenship Skills reflection
}

\begin{abstract}
Research in the EFL classroom has constantly highlighted the value of authentic materials to teach English because they help learners integrate various aspects of language learning and provide exposure to real-life language. However, authentic materials are not yet used as desirable at the college level, nor does a pedagogical model about how to use them in the classroom exist. Thus, an action research study was carried out to analyze how using authentic video materials helped low-intermediate and intermediate level students develop their communicative competence concerning vocabulary gains. Additionally, it explored the effects authentic video activities had on students' performance and their perceptions about using such videos. An inductive approach was used to analyze the data collected through class observation field notes, a survey, students' artifacts, and an informal talk. The results showed that, through guiding exercises, students used new vocabulary from the videos accurately. Also, authentic videos appeared to have a positive effect on motivation and triggered reflection on global citizenship skills.
\end{abstract}

Keywords: action research, authentic video materials, vocabulary learning, motivation, global citizenship skills.

\section{Resumen}

Investigaciones en contextos de enseñanza de inglés como lengua extranjera han señalado constantemente el valor de los materiales auténticos en la enseñanza de inglés ya que éstos ayudan a los estudiantes a integrar varios aspectos del aprendizaje de la lengua y los 
exponen al uso del lenguaje en la vida real. Sin embargo, los materiales auténticos no son muy utilizados a nivel universitario y no existe un modelo pedagógico que guíe su implementación. Así, un estudio de investigación acción fue realizado para analizar cómo el uso de videos auténticos influencia la competencia comunicativa en relación con el aprendizaje de vocabulario de los estudiantes de inglés de nivel intermedio bajo y nivel intermedio. Además, el estudio investigó el impacto que tuvieron los videos auténticos en el desempeño de los estudiantes y su percepción acerca de los mismos. Los instrumentos de recolección de datos incluyeron notas de campo, una encuesta, productos elaborados por los estudiantes y una charla informal. Los resultados demostraron que las guías desarrolladas para cada video permitieron a los estudiantes utilizar el nuevo vocabulario de manera adecuada. Los videos auténticos también tuvieron un efecto positivo en la motivación de los estudiantes y favorecieron la reflexión de los estudiantes sobre habilidades de ciudadanía.

Palabras clave: videos auténticos, aprendizaje de vocabulario, motivación, ciudadanía global

\section{Introduction}

Using authentic materials to teach English has proved to be an effective resource in English as a Foreign Language contexts (EFL). This kind of materials help learners work holistically since they integrate various aspects of language learning such as pragmatics, grammatical structures, pronunciation, and vocabulary including idioms and other language chunks (Gilmore, 2011). Teachers may find that bringing real-life materials into the classroom is a powerful tool to expose students to rich input that is not present in textbooks or any other type of instructional materials. Despite the benefits found, authentic materials 
such as videos are not still widely used or more deeply exploited at the college level, so it is still needed to implement a more frequent, systematic use of authentic videos during classes. Moreover, learners will get the benefit from such implementation, which would help them upgrade their language level in aspects like vocabulary learning. Studies like those of Gilmore (2011) and Segueni (2016) have suggested positive effects of using authentic materials like songs, readings, and videos. Learners exposed to such materials improved not only their communicative competence in areas such as speaking, pragmatics, and vocabulary learning, but also their confidence in understanding and speaking English. However, authentic materials are not yet used as desirably at the college level, nor does a pedagogical model exist about how to use them in the classroom.

Teachers at the college level may profit from getting a better understanding of what authentic materials are, the positive gains they bring for learning, and how they can be used

in the classroom. For example, when surveyed about their own use of authentic materials in the classroom, a small group of teachers at the college where this study was carried out answered that the implementation of authentic materials was necessary and training could be helpful. Likewise, Castillo, Insuasty and Jaime (2017) highlighted the need for teachers in general to develop expertise in the implementation of authentic materials as there are possible drawbacks such as inefficient time management, overlapping of learning objectives, and wrong selection of materials.

\section{Theoretical Background}

\section{Communicative Competence}

The notion of communicative competence has been a basic tenet in the English teaching field for years dating back to the late sixties and early seventies. Thus, Hymes' initial 
definition of such notion has evolved into a more complex, descriptive model comprising components such as linguistic, sociocultural, strategic, and discourse competence (Canale 1983, in Celce-Murcia, Dörnyei, and Thurrell, 1995). Gilmore (2007) asserted that five components are accepted as the core of a model for communicative competence. These are briefly explained as follows.

\section{Linguistic competence}

This is the competence that has received the most attention in English teaching and entails knowledge related to lexis, morphology, syntax, phonology, and orthography (when written) of the language.

\section{Pragmalinguistic competence}

Knowledge of this component implies understanding of what a given utterance expresses beyond its literal meaning as represented by speech acts and the speaker's intentions underlying words.

\section{Sociopragmatic competence}

Also known as sociocultural and actional competence (see Celce-Murcia et al., 1995), this component entails knowledge of the social and cultural systems of a language and what is considered appropriate within those systems. It moves beyond words and utterances into non-verbal features accompanying language such as gestures, body language and proxemics.

\section{Strategic competence}

Knowledge of this component means understanding and using communication strategies appropriately as required by the situation. Gilmore (2007) listed four subcomponents constituting this strategy, namely, avoidance or reduction strategies, compensatory 
strategies, stalling strategies, and interactional strategies, while Celce-Murcia et al. (1995) considered self-monitoring strategies in addition to the four mentioned before.

\section{Discourse competence}

This competence refers to the knowledge required to produce coherent and cohesive texts at the spoken and written levels. Celce-Murcia et al. (1995) suggested five subcomponents to this competence: Cohesion, deixis, coherence, genre/generic structure, and conversational structure.

Research has shown positive outcomes in regard to the effect of authentic materials on students' communicative competence (Gilmore, 2007, 2011; Segueni, 2016; Castillo, Isuasty and Jaime, 2017) and pragmatic competence (Martínez-Flor, 2008; Washburn, 2001). Other studies have also reported learning gains in listening skills development (Ghaderpanahi (2012), Kraiova and Tsybaniuk (2015). Although other studies such as Ghanbari, Esmaili and Rezam's (2015) have unveiled some of the benefits of authentic materials in vocabulary learning, no study was found that approached vocabulary learning following the concept of involvement as proposed in this study.

\section{Word Knowledge}

As word knowledge is a basic skill for students in beginning levels, this paper will focus on the lexis component of linguistic competence as part of communicative competence. In regard to lexis, authors like Nation (2001) have elaborated on the concept of what it means to know a word. He, thus, proposed to explore word knowledge considering the receptive and productive scales of knowledge. Broadly speaking, the former refers to perceiving when reading or listening to a word, while the latter implies the desire to express meaning when speaking or writing. Nation pinpointed that all the aspects of word knowledge can be 
accounted for by using the receptive/productive types of knowledge. Thus, knowing a word can be determined from a receptive or productive perspective taking into account the word aspects of form, meaning, and use. Form is equivalent to recognizing a word when it is heard (spoken form) or spelled (written form). Meaning and meaning-form connection implies evoking a concept and then being able to connect it with a given spoken or written form. Use has to do with knowing about the grammatical function of a word, its collocations, and restrictions of use such as register and frequency.

These aspects, mainly the ones concerning form and meaning, were considered in the activities of this project to determine students' word knowledge and vocabulary gains as the participants were beginner English learners.

\section{Authentic Materials}

Authentic materials have been defined differently over the last three decades, but two of the most accepted definitions are used for this study. Morrow, 1977 (cited in Gilmore, 2007) defined authentic materials as "a stretch of real language, produced by a real speaker or writer for a real audience and designed to convey a real message of some sort” (p. 98). Zyzick and Polio (2017) opted for a more specific definition, "authentic materials are those created for some real-world purposes other than language learning, often, but not always, by native speakers for native speakers" (p. 4). The authors clarify that text refers to any spoken or written language that is part of a set of materials. They also explain that materials can include pictures without any language. That is to say, both spoken and written language samples are considered authentic texts.

Some typical difficulties have been associated with authentic texts. Zyzick and Polio (2017) bring up a common concern among educators: finding appropriate authentic texts and 
creating good activities to exploit them is time consuming. It has been also assumed that using authentic materials at beginning levels can result in both teacher and student's frustration. Richards (2001) points out that "authentic materials often contain difficult language, unneeded vocabulary items and complex language structures, which causes a burden for the teacher in lower-level classes" (p. 253). Al-Azri \& Al-Rashdi (2014) point out that if the authentic materials are beyond the learners' ability or level, students might feel demotivated and discouraged from learning the target language. Nonetheless, all these authors do advocate for the use of authentic materials considering the characteristics of the instructional contexts where they are implemented.

Additionally, texts that are too challenging for learners, plus a not well-designed task may bring demotivation and minimal learning. Nevertheless, researchers such as Castillo et al. (2017) suggested useful ways to deal with such difficulties. They argued that authentic materials need to be explored within a thorough methodological framework that enables learners to acquire both receptive and productive skills and allows them to put into practice what they learn while developing pedagogical communicative projects. Each lesson is to be planned in a detailed way by taking into account the transitions between the pre-activity, the actual activity, and the post-activity. Maxim (2002) gave high importance to the task designed to address the content of the authentic material because that task has a potential effect on language learning. His 2002 study with beginner learners of German demonstrated that providing students with a framework for achieving comprehension was key to successfully guiding students' work while reading a short novel in German. Bearing these considerations in mind, our pedagogical intervention included worksheets designed by the researchers to walk learners in English I and English II courses through the video 
content. Learners were guided through pre-, while- and post-watching stages that showed a logical progression in cognitive demand.

\section{Involvement Load Hypothesis}

Authentic videos have been often used in the classroom to develop students' listening skills by exposing learners to pre-listening activities focused on pre-teaching vocabulary (Ghaderpanahi, 2012; Kraiova and Tsybaniuk, 2015); however, this strategy alone does not guarantee vocabulary learning (Chang and Read, 2006), rather intentional and deep work on target items needs to be done. Laufer \& Hulstijn (2001) suggested that three key factors lead to retention of words: need, search, and evaluation. These factors combined constitute involvement, and thus, the load involvement hypothesis. The need component is the motivational dimension of involvement, which is concerned with the need to achieve. When reading, for example, if a word is essential for the comprehension of a sentence or passage, the learner will experience the need to understand it. When writing or speaking, if the learner wants to refer to a concept or an object, s/he will need to find the L2 word that is unfamiliar. This 'finding', in turn, leads to search and evaluation, the cognitive components of involvement. Search is defined as the effort to find the meaning of an unfamiliar word by using a dictionary or consulting an expert, while evaluation entails deciding whether a word fits a given context. In an L2 writing task, for instance, in which an L1 word is looked up in the dictionary, it is necessary for the learner to assess which is the most suitable translation to be chosen for the specific meaning that is intended to be conveyed in the L2 context.

Laufer and Hulstijn (2001) claimed that words that were processed with a higher involvement load would be better retained than words which were processed with a lower 
involvement load. Thus, the activities designed for this paper included various levels of involvement with vocabulary items to help participants' learning.

\section{Global Citizenship Skills}

Changes in the global context have brought a significant need for global citizenship education that enables learners of all ages and backgrounds to become truly global citizens. Authentic video materials are a rich source of information on topics and issues that are relevant to our learners as they currently face an increasingly globalized world. The UNESCO (2014) sustains the following in regard to global citizenship:

It is also a way of understanding, acting and relating oneself to others and the environment in space and in time, based on universal values, through respect for diversity and pluralism. In this context, each individual's life has implications in day-to-day decisions that connect the global with the local, and vice versa. (p.14)

Global citizenship education entails defining global citizenship education goals, learning objectives and competencies, based on three interrelated domains of learning: cognitive, socio-emotional and behavioral. The cognitive domain entails acquiring knowledge, understanding and critical thinking about global, regional and national issues. The socioemotional domain involves building a sense of belonging to a common humanity, sharing values and responsibilities and appreciating and respecting differences and diversity. Finally, the behavioral dimension calls for ethical and responsible actions and understanding of ethical issues such as climate change, consumerism, and sustainable development (UNESCO, 2014). For the purpose of this paper, we focused on the socioemotional and behavioral domains of global citizenship education because the topics 
targeted through the authentic videos showed mainly characteristics related to such domains.

At a local context, the Colombian Ministry of Education (2004) proposed the Basic Standards for Citizenship Competences which must guide the teaching practices of all teachers, including language teachers. The competences contained in this official document concur with the global citizenship skills stated by the UNESCO. The citizenship competences include the ability to live in peace with others, respect differences and appreciate diversity.

\section{Literature Review}

Several research studies have demonstrated a positive effect of the integration of various authentic materials on the development of students' communicative competence in English. Gilmore's (2011) study reported on a 10-month classroom-based longitudinal investigation, exploring the potential of authentic materials to develop Japanese learners' communicative competence (i.e. linguistic, pragmalinguistic, sociopragmatic, strategic, and discourse competencies) in English. The results indicated that the experimental group outperformed the control group in five of the eight measures, suggesting that the authentic materials and their associated tasks were more effective in developing a broader range of communicative competencies in learners than the textbook materials.

Similarly, Segueni (2016), explored the effect of a whole semester of exposure to authentic materials on the development of foreign language learners' communicative and pragmatic competence (i.e., pragmatic and discourse competence). The results of the study showed that authentic materials not only developed a wide range of communicative competences 
but were strongly appealing to the participants in the experimental group. The increase demonstrated by the experimental group in their confidence in understanding and producing speech acts was the most significant result. Students became increasingly comfortable hearing English and they understood more of the authentic materials that they were exposed to. Furthermore, according to Segueni, such type of materials not only had a positive impact on learners' motivation but proved fit to learners' diverse learning needs as well.

In a local context, Castillo, Isuasty and Jaime (2017) carried out a research study in a foreign language school at a Colombian public university. Its main purpose was to analyze the extent to which the use of authentic materials and tasks contributed to the enhancement of the communicative competence on an A2 level English course. A mixed-study composed of a quasi-experimental and a descriptive-qualitative research design was implemented by means of a pre-test, a post-test, observations, semi-structured interviews, surveys, and diaries. The findings showed that the use of authentic materials and tasks, within the framework of a pedagogical project, had an impact on students' communicative competence progress and on the teaching practices in the experimental group.

Notwithstanding, the inherent difficulty (i.e. speed, reduced forms, and colloquial language) of aural authentic materials has usually prevented educators from using them with students at beginning levels. However, Maxim (2002), presented the design, results, and implications of a study involving beginning college-level language students who read a 142-page romance novel in their first semester of German. The study explored the ways extensive reading at a beginning level affected general reading comprehension and language proficiency. Maxim's study concluded that students in the first semester of 
German were able to read a long and unedited novel. In other words, his study rejected the often-mentioned difficulty learners at the beginning level have when working with authentic materials. Students' success was favored by two key procedures Maxim carried out during the intervention. First, a systematic approach to reading the novel guided learners throughout processes of identification, summarizing, synthesizing, and analyzing. Second, in-class group reading allowed students to work together towards comprehension, share prior knowledge and reading strategies, and construct meaning from the text.

On the other hand, other studies have evidenced the usefulness of authentic materials in the development of listening skills and vocabulary learning. Ghaderpanahi (2012) examined the influences of authentic aural materials on the listening ability of thirty female undergraduate psychology majors studying English as a foreign language. The findings of this study indicated that listening comprehension in EFL students appeared to have improved after they had experienced authentic listening materials in class. In addition, Kraiova and Tsybaniuk (2015) analyzed the impact that authentic videos had on the development of listening skills in a foreign language teaching process and on the ways to increase the effectiveness of authentic video lessons in terms of listening skills development. The implementation of authentic videos into the process of listening comprehension development demonstrated positive results in increasing the motivation of students by involving them into a real communication process, showing them the natural way of speaking, providing them with authentic cultural information and facilitating cultural adaptation.

In regard to the role of authentic materials and vocabulary learning, Ghanbari, Esmaili and Rezam (2015) focused on teaching vocabulary using authentic materials and its influence 
on learners' vocabulary achievement. To this end, a population of 80 female Iranian EFL learners aged 17 to 20 were selected. The control group received new vocabulary through their English textbook in each session and the experimental group received the same vocabulary through an online newspaper in each session. After a month, post-tests were run among all of the participants in both control and experimental groups. The analysis of data showed that the vocabulary knowledge of the participants developed in both groups, but the experimental group significantly outperformed the control group.

Putting it all together, this body of literature suggests that the use of authentic materials contributes to the development of students' communicative competence and has a positive effect on listening skills and vocabulary learning. Besides, teachers need to guarantee that there is appropriate guidance based on learners' characteristics such as level and age.

\section{Methodology}

\section{Participants and Setting}

Homogeneous sampling was used to select the participants bearing in mind that students in Low Intermediate (English I) and Intermediate English (English II) courses at the research site shared similar defining characteristics. These students were majoring in English teaching at a private bilingual college (Institución Universitaria) where they took English lessons four days a week during two-hour periods. Ten participants (five female and five male) were in second semester and 14 (10 female and 4 male) in third semester of the program respectively, and their English level ranged between A2 and B1 in the Common European Framework. These students were between 17 and 20 years old and they belonged 
to different socioeconomic backgrounds. Each teacher researcher was in charge of teaching one of the courses and followed similar procedures during the intervention. That is, each researcher used the course textbook units to decide on a theme and then selected a related authentic video from the web or DVDs of TV shows. Next, they designed a worksheet to facilitate students' understanding and analysis of the video content through pre-, while-, and post- watching activities.

All the participants in the study agreed to take part in the research study voluntarily and no grades were associated with their participation.

\section{Research Questions}

The following were the research questions that guided this study:

1. How does the use of authentic videos impact students' linguistic competence as expressed in vocabulary gains in low-intermediate and intermediate courses at a private college?

2. What is students' perception of the use of authentic videos in the classroom?

3. What other effects are observed in students when they are exposed to authentic videos? The purpose of this study was threefold. First and foremost, the objective was to analyze how using authentic videos helped low intermediate (English I) and intermediate (English II) English students learn vocabulary. Secondly, this study aimed at inquiring about students' perception after using authentic videos and, thirdly, determining whether these kinds of videos had any other influence on students' learning.

It was hypothesized, thus, that by being exposed to authentic videos systematically, students at beginning levels would increase their vocabulary while showing a positive 
reaction towards watching such video clips in class. Finally, they might raise awareness of social and cultural topics and become more motivated.

\section{Authentic video materials}

The authentic videos used in this study ranged from topics on the environment to topics on brain science and cultural practices. Videos were mainly taken from YouTube and were chosen because of the related topics in the course syllabus. The video related activities were carried out every two weeks and were often developed over the course of two or three lessons. The researchers created a worksheet to guide students' work on each video. Typically, the pre-watching stage involved connecting to students' background and experience and working on new vocabulary. During the video watching stage, students were usually asked to pay attention to new vocabulary and to answer comprehension questions. Finally, at the post-watching stage learners were encouraged to discuss their views, or to create a product (e.g., a poster, brochure, paragraph, etc.) based on the content of the video.

\section{Research Design}

\section{Action Research}

Action Research as a design can be used when educator researchers seek to improve their own educational practices by identifying a problem or issue, systematically collecting and analyzing data, and proposing a plan of action (Creswell, 2012).

This was an action research study designed to shed light on the effective use of authentic video materials in the EFL classroom at the college level. The researchers followed a 
systematic procedure to gather information about the effects of authentic video-use on language learning in order to improve their educational practices and contribute to students' learning. This is one of the ultimate purposes of action research as highlighted by Creswell (2012) when stating that "the scope of action research provides a means for teachers or educators in the schools to improve their practices of taking action and to do so by participating in research.” (p. 577). Following the stages of the action research design, the researchers identified the need for students in both English I and II courses to be exposed to real use of the language while working on their vocabulary skills as a by-product. After obtaining students' consent, the researchers began collecting data by periodically (i.e., every two weeks) showing a video clip and having students answer questions about it. Besides, students completed questions to reflect on their reactions towards the video. A more detailed description of the instruments used for data collection, namely, class observations, students' artifacts, surveys, and informal talks can be found as follows:

- Class observation notes were taken to register students' reactions towards the materials and activities proposed, their potential use of new vocabulary, and other events worth registering (e.g., students' chats and comments while watching the videos)

- Students' artifacts were gathered to analyze how students processed the new vocabulary items taken from the authentic videos. These artifacts consisted of video worksheets with pre-, post- and while-watching activities.

- A survey was answered by students every time they worked on authentic videorelated activities to know their perceptions of using such materials in the class. They 
were allowed to use either English or Spanish to answer, so language would not be a barrier for them to express themselves.

- Informal and individual talks between the researchers and the participants took place after the intervention. The talks inquired about learners' opinions on the authentic video related activities carried out during the intervention.

Next, the data from both English I and English II courses were organized and transcribed following an inductive approach, going from detailed data (e.g. transcripts of survey answers, informal talks, and field notes) to general codes and themes. The data were segmented and labeled with codes that were examined and collapsed into broad topics. To this end, an excel chart was created to classify the data under main categories or themes. This procedure was followed with the data obtained from the data sources looking for similar or differing patterns (i.e., class observations, artifacts, surveys, and informal talks). Vocabulary gains were analyzed by observing students' outcomes in the worksheet activities and their own comments about vocabulary they had learned. Then the findings of these observations were reported descriptively. Finally, a matrix was used to ensure the triangulation of the data gathered as illustrated in Table 1.

\section{Table 1}

\section{Data Triangulation}




\begin{tabular}{lcccc}
\hline \multicolumn{1}{c}{ Data sources } & $\begin{array}{l}\text { Direct observation } \\
\text { and field notes }\end{array}$ & $\begin{array}{l}\text { Students' } \\
\text { artifacts }\end{array}$ & Surveys & $\begin{array}{l}\text { Informal } \\
\text { talks }\end{array}$ \\
Variables & $\checkmark$ & $\checkmark$ & $\checkmark$ & $\checkmark$ \\
\hline Vocabulary gains & $\checkmark$ & $\checkmark$ & $\checkmark$ & \\
Students' perception & $\checkmark$ & & $\checkmark$ & $\checkmark$ \\
\hline
\end{tabular}

\section{Findings}

\section{Vocabulary Gains}

In order to find out the effect of authentic video materials on students' vocabulary gains (research question 1), students' artifacts (See Appendix A and B) from both groups English I and English II, which evidenced their work on new vocabulary items, were analyzed. Such analysis was done taking into account Laufer \& Hulstijn's (2001) Involvement Load Hypothesis and Nation's (2001) considerations on vocabulary knowledge as synthesized in Table 2.

Table 2

Student Involvement Load Levels and Vocabulary Learning 


\begin{tabular}{llc}
\hline Involvement load level & Authentic video related activity & Level of vocabulary \\
(Laufer \& Hulstijn, 2001) & & knowledge explored by \\
& & students (Nation, 2001) \\
\hline 1. Low Involvement & Make a list of new vocabulary items that you & Form recognition \\
2. Medium Involvement & Find the meaning of a new vocabulary item and & Form-meaning \\
& complete a sentence. & connection \\
3. High Involvement & Find the meaning of a new vocabulary item, its & Form-meaning-use \\
& pronunciation (IPA), and part of speech. Copy an & connection \\
& example from the dictionary and then write your & \\
& own examples.
\end{tabular}

The activities included in the artifacts covered various levels to approach word knowledge. Some of them were focused on the most basic concept of word knowledge which is form recognition as proposed by Nation (2001); one such example was recalling new words from the video or making a list of unknown items. Another level of vocabulary knowledge was explored through those activities in which students had to find the pronunciation and meaning of the word (meaning-form connection), search one example phrase or sentence in the dictionary, and then write their own examples (use). Similarly, students got deeper into exploring word knowledge by, for example, working in one activity with two handouts (form A and form B) in which besides exploring the aspects described above, they had to share their exploration with a classmate (again form, meaning, and use - see appendix C). Additionally, in another activity learners were asked to create a brochure of an unknown tourist place in Colombia which incorporated the vocabulary, mainly adjectives, introduced 
in the video. In most activities, students dealt with aspects related to the form-meaning connection and use of new vocabulary items.

Laufer and Hulstijn (2001) posited that retention depended upon three components that together constitute involvement, namely, need, search and evaluation. Thus, the more students are prompted to explore each of these components when trying to understand a vocabulary item, the more they will recall it. That is, the more involvement with an item, the higher its retention. As considered earlier, students were guided to work on vocabulary items in activities that had various levels of involvement. In sum, students' artifacts demonstrated consistent and high load involvement with new vocabulary items, which is conducive to vocabulary retention.

Furthermore, although the participants in English I and English II were not asked explicitly about vocabulary learning, students reported recurrently that they were learning vocabulary as they developed the proposed activities based on the video content. Some comments exemplify this conclusion:

English II, student 7: ...Moreover, I learnt more vocabulary and more important expressions. (Survey, February 27, 2018)

English II, student 8: ...the things for example in the guides, that you gave us, I think was very useful because we try to find the meaning in Spanish and in English and do examples and I think that helped us in our learning. " (Informal talk, June 7, 2018)

\section{Students' Perceptions}

In order to discern students' perception about using authentic videos in their English classes (research question 2), the surveys from both English I and II, field notes and the data 
gathered in the informal talk with the participants in English II were analyzed. The analysis revealed the following categories:

\section{Encountering and dealing with 'difficulties'}

One category that was foreseen based on the literature read and previous studies concerned the difficulties students might find while watching authentic videos. Based on students' answers in the survey, it could be determined that difficulties were caused by two related factors: lack of vocabulary knowledge, and difficulties in listening to follow the speaker. For the former, students said that they struggled to understand some parts of the videos because of the new words and expressions used by the speakers. This was a generalized answer in both English I and English II courses. Here are some examples in the students' own words (answers were transcribed as written by the students):

English I, student 1: Muchas palabras dificiles de entender (A lot of words that were difficult to understand). (Survey, February, 2018)

English II, student 5: I didn't understand some parts from the video because I didn't know vocabulary. (Survey, April 12, 2018)

The second difficulty reported by students was understanding when listening, which they attributed to their perception of speakers' fast rate of speech.

English I, student 1: Muchas palabras difíciles de entender ya que hablan rápido (a lot of words that were difficult to understand because they (people in video) spoke fast). (Survey, February, 2018)

English II, student 2: "the woman was speaking a little fast. So, sometimes it was difficult to understand her." 
Notwithstanding, a second category related with these difficulties emerged (in English I), which is how students themselves reported what they did to succeed in understanding despite their struggling with vocabulary and fast speech (as they perceived it). Most of the answers gathered here were a response to the question: what difficulties did you have while completing the activities about the video?

English I, student 11: Durante el video encontre muchas palabras desconocidas, que luego iba relacionando con las imágenes y vocabulario ya conocido. (While watching the video, I found a lot of unknown words that I related to the images and vocabulary already known). (Survey, February, 2018)

English I, video 2, student 2: Algunos significados pero los comparaba con la imagen y así entendia (some [word] meanings, but I compared them with the images and so I understood). (Survey, March, 2018)

\section{Exploring a learning source}

Despite the difficulties encountered, another category observed in students' comments is how they saw authentic videos as a rich source of learning in terms of linguistic aspects and content. Students' idea about learning vocabulary from videos was iterative in answers to questions such as what would you like to learn from this video? What did you like about this video? What would you like to tell your teacher about this video? and what is your opinion of the video activities done in class? Students particularly highlighted that the videos watched could help them learn new vocabulary and improve their listening comprehension. 
English I, student 9: It is great because first you learn and second you enjoy while watch the video and probably then you could remember more vocabulary. (Survey, May 29, 2018)

English II, student 11: We learn many many vocabulary about everything, we improved our listening. (Informal talk, June 7, 2018)

Similarly, students' comments and answers in the survey, evidenced that students saw videos as a way of learning about the content showed in those.

English I, student 5: That I like this kind of activity because are realistics and we learn something else than English. (Survey, April 17, 2018)

English II, student 12: ... it was interesting meet new topics and learn more about the history, about culture about other things that we didn't before. (Informal talk, June 7, 2018)

Generating motivation

English I and English II students expressed that they enjoyed watching authentic videos because they could learn something new other than English while still learning English; when asked What would you like to tell your teacher about the activity? and what's your opinion about the video activities done in class? students highlighted the benefits of learning new vocabulary and being exposed to natural speech where they could perceive how people speak in a more natural context (i.e., even though the language of an Internet or TV show is scripted, it is not modified for an ESL audience). They thought that this was a good strategy for them to learn. Likewise, students expressed their appreciation for being shown these videos. 
English I, student 1: I really enjoyed the video because I learnt new vocabulary and new things about animals intelligence. (Survey, May 2018)

English II, student 13: ... es un tema de mi interés, fue entretenido y brindó información diferente que desconocía (it is a topic of my interest, it was entertaining, and gave me information that I did not know). (Survey, April 30, 2018)

The categories found in the surveys were further supported by some of the findings from class observation field notes, which also provided a description of students' reactions while video watching. These entries illustrated, for example, how videos were used as a learning source; thus, after watching video 7 for the first time, students used some of the language from the video to answer a teacher's question about the video topic. English I: “Google used a voice assistant in the summer." (April 2018). At the beginning of that class session, the teacher-researcher asked students if they knew what a voice assistant was, and they said they did not, so this was a new idea for them. However, they were able to 'pick some language up' and use it after watching the video.

Entries also illustrated that students found difficulties while watching the video, so the teacher-researchers took actions to help understanding: "I asked students not to worry about the meaning of some words since they would probably understand with the content and the images shown in the video." Additionally, the teacher-researchers observed that students related their personal experiences to those shown in the video; thus, in students' response to video 1 (stories of survival), the teacher commented: English I "Students told the class their pick and explained. I was delighted to hear their answers and each student had related to a particular story (they related it to their personal life)." Similarly, a student in English II, reacted towards video 4 (Water in Africa) and related it to her personal experience: 
"Student 12 predicted that Naomy, the main character in the video, fetched water every three days. However, when she realized Naomy made several trips a day to the well, the participant said: ... "and I have water at home, that was hard for her [Naomi]."

Finally, entries demonstrated that students were interested, and the videos were motivating for them, (English I, Video 7) "They showed interest while watching the video. They reacted towards the babies' and dogs' behavior shown in the video (e.g., they made gestures of surprise, they giggled)."

In short, the results obtained support the hypothesis that by being exposed to authentic videos systematically, students increased their vocabulary. Meanwhile, they also became more motivated and raised awareness of social and cultural topics as reflected by data in the survey and the observation field notes. Another finding from these sources revealed that global citizenship was triggered by the video clips content.

\section{Global Citizenship Education}

A noticeable impact of the exposure of students to authentic video materials and related activities was observed in English I and II (research question 3), such impact was related to global citizenship education and its core conceptual dimensions (see UNESCO, 2014).

First, the answers collected from students showed their reflection on the content presented in the videos. Some common themes that appeared here were how the situations portrayed led students to make a connection with their personal lives and pondered on aspects like knowing themselves, believing in themselves, raising their awareness towards an issue they did not know or to which they had not paid attention before. 
English I, student 1: Sí, es un video que crea conciencia acerca de las situaciones que vivimos sin darnos cuenta (Yes, it is a video that raises awareness of the situations that we live in without realizing. (Survey, March 6, 2018)

Second, some understanding of ethical issues such as climate change, consumerism, and sustainable development was also evident in the comments made by students after watching different videos. For example, some participants reflected on habits of consumerism and caring about the environment.

English II, video 1, The Life Cycle of a T-shirt, student 3: ... no sabía cómo era el proceso para hacer las camisetas ahí es donde nos damos cuenta todo lo que tiene que sufrir el medio ambiente para sacar una camiseta y muchas veces uno no nota eso entonces por ejemplo se le rompió un poco y ya vamos a botarla sabiendo que podemos hacer otras cosas con estas. (I did not know the process needed to make T-shirts, now I realize all the harm the environment has to suffer in order to get a T-shirt. Many times, we do not notice it, for example when it gets a bit ripped we throw it knowing that we can make other things out of it. (Survey, February 7, 2018). The same video triggered the following conversation: Teacher researcher: Do you think you are making an impact on the environment with your clothes?

Student 12: "Yes, after watching the video, I know"

Teacher researcher: What actions will you take to reduce the impact you make on the environment in relation with your clothes? Students worked in pairs and as a class came up with ideas like donating clothes, buying less clothes, buying second hand clothes and making new things out of old clothes. (observation field notes, February 14, 2018) 
Third, students also reflected attitudes that appreciate and respect differences and diversity, another tenet of global citizenship education. For example, this is a student's point of view after watching a video on a Canadian couple who lived on a homemade island in a secluded cove.

English I, student 3, video 3: I like the video because I could to learn other culture, Also I knew the situations of other kinds (Survey, March 2018)

English II, student 14: "Yes, I like the video because show me that exist different ways to live, also, we have just one perception of live that is a perfect house”. (Survey, April 30, 2018).

Another student reflected on video 3 about Jane Goodall's work with chimpanzees in Africa:

English II, student 10: “... with this video I realized that in the world there is many people with customs and interests very different and unique!". (Survey, April 30, 2018)

\section{Discussion}

To begin, the results show that students encountered difficulties to comprehend the videos shown, as reported in the literature as one of the concerns that prevents teachers from using authentic videos or using them more often (see Zyzick and Polio, 2017). However, participants expressed that in the end they understood the main points of the clip and even wrote specific messages about ideas that they had understood. Two factors could have contributed to participants' understanding despite their struggle with unknown words and perceived fast speech rate: the kind of video format chosen and the format of the activities accompanying the video clip. 
Concerning video format, the researchers of this project selected videos in which the audio was closely or directly related to the images presented. As for the activity format, we believe that activities based on authentic videos require to be scaffolded carefully and adapted to the learners' level. Often, authentic video content might be too difficult for students at beginning levels (see Al-Azri \& Al-Rashdi, 2014); however, such content can be made accessible to learners through the type of task or activity that the teacher creates (see Zyzick and Polio, 2017; Maxim, 2002).

Working with authentic videos is not that different from working with non-authentic ones as using both resources involves pre-, while-, and post watching stages. Typically, at the pre-watching stage, students are prepared to watch the video by connecting to their background knowledge and experience and by pre-learning some vocabulary. While watching the video, students can focus on answering specific questions, working on vocabulary or doing a specific action. Nonetheless, it is the follow-up task that seems to be essential at the post-watching stage.

At that stage, apart from asking learners to reflect on the content or answer specific questions, it is capital to demand high involvement with new vocabulary items as suggested in the Involvement Load Hypothesis (Laufer and Hulstjin, 2001) for example by creating a new product (e.g. a brochure, a story, a survey, etc.) that forces students to use the new vocabulary items. In this process, learners are required to go back to the language worked on at the pre- and while- stages (i.e., need); find the vocabulary they need including aspects such as pronunciation, meaning, part of speech, etc., (i.e., search); and analyze how to integrate it within sentences or paragraphs (i.e., evaluation). Designing activities with the 
features mentioned helped students retain new vocabulary as illustrated by students' artifacts and comments.

It is worth mentioning here that the nature of this project was qualitative, so the vocabulary gains based on the artifacts are rather descriptive; notwithstanding, the researchers acknowledge that a using a quantitative instrument to measure vocabulary gains could provide a more robust evidence of participants' vocabulary learning.

Furthermore, the implementation of authentic video related activities boosts learners' motivation as video clips are seen by students as a rich learning source of both content and linguistic aspects as evidenced by their comments. The content of the videos gives learners the chance to learn about new topics and raise awareness of issues they were unaware of or have not paid attention to before. This seems to have a significant impact on students' enjoyment of the classes as they can learn something new other than English, while still learning English. Likewise, as reflected by the data, students feel motivated as authentic videos benefit their vocabulary learning and contribute to the development of their listening skills. However, as the content of an authentic video might not be necessarily motivating or connected to students' context, it is crucial to design pre-, while- and post-watching activities that facilitate not only learners' understanding but also help them establish connections between the video content and their reality. This will ensure that language learners feel more confident in their ability to understand the language and feel more motivated when the video-related activities are meaningful to them.

Lastly, authentic videos constitute a tool that contributes not only to improving vocabulary knowledge but also to raising awareness of concerning and prevalent issues that affect today's learners. Such issues are connected with the domains of learning of global 
citizenship education that relate to consumerism, sustainable development and valuing and respecting cultural diversity (UNESCO, 2014). Although the participants in this study did not reach an in-depth discussion on these domains given their language and maturity level, they were interested and reflected on these pressing issues. Further research could look at how authentic video materials could further help the development of global citizenship skills.

To conclude this section, here are some limitations worth noting for future researchers. First, the number of participants in this study was small (24), so these findings are not intended to be generalizable. Also, because these learners were students majoring in language teaching, it is recommended that practitioners be aware that a different target audience could respond differently to video-related activities. As mentioned before, the use of a pre- post- test to measure vocabulary gains is advisable to strengthen learning findings. It is recommended that practitioners consider.

\section{Note for Practitioners}

To deal with two of the most common difficulties regarding authentic videos, unknown vocabulary and fast speech rate, teachers are advised to scaffold the video-related activity carefully and adapt it to students' level. Here are some ideas:

- $\quad$ At the pre-stage, teachers can help learners build or activate background and preteach key vocabulary by having them search for meaning, part of speech, IPA, and use in context. 
- $\quad$ During the video watching stage, teachers can give students tasks that fit their proficiency level. For example, listen to the order in which certain vocabulary words appear in the video, make predictions, answer non-complex comprehension questions.

- $\quad$ Teachers could design a post task that demands students' high involvement. This means creating a product (i.e., story, a brochure, a role play, a poem, etc.) that pushes students to use the new vocabulary and evaluate if it fits appropriately in the given context.

- $\quad$ Teachers need to analyze the video content to decide on the most suitable activity that fits it. For example, in a video about how a woman's life was changed by having water, a teacher can have learners make a parallel between life before and after water.

- Teachers could draw students' attention to idiomatic and real-life expressions to complement the unknown vocabulary they selected on their own.

\section{Conclusions}

Authentic videos provide learners with real-life language input making it possible for them to develop skills like vocabulary learning. In this regard, it is recommended that learners are provided with opportunities to engage with new vocabulary items at a higher level of involvement that includes the need to use the item, the search for meaning, pronunciation and part of speech, and the evaluation of the use of the item in a given context. The difficulties associated with the use of authentic video-clips can be solved by selecting a video in which the language clearly matches the images shown. Such video needs to be accompanied by an activity format that facilitates understanding. This way, learners will be more prone to embracing those difficulties as a challenge given the benefits that they encounter in terms of learning as reported by participants' perceptions in this study. Finally, 
video-clip content constitutes a tool to foster not only linguistic learning, but also students' reflection upon current issues such as global citizenship.

\section{References}

Al Azri, R. H., \& Al-Rashdi, M. H. (2014). The effect of using authentic materials in teaching. International Journal of Scientific \& Technology Research, 3(10), 249254.

Castillo Losada, C. A., Insuasty, E. A., \& Jaime Osorio, M. F. (2017). The impact of authentic materials and tasks on students' communicative competence at a Colombian language school. PROFILE Issues in Teachers' Professional Development, 19(1), 89-104. Retrieved from $\underline{\text { http://dx.doi.org/10.15446/profile.v19n1.56763. }}$.

Celce-Murcia, M., Dörnyei, Z., \& Thurrell, S. (1995). Communicative competence: A pedagogically motivated model with content specifications. Issues in Applied linguistics, 6(2), 5-35.

Gilmore, A. (2007). Authentic materials and authenticity in foreign language learning. Language Teaching, 40(2), 97-118.

Gilmore, A. (2011). “I Prefer Not Text”: Developing Japanese Learners' Communicative competence with Authentic Materials. Language Learning, 61, 786-819. doi:10.1111/j.1467-9922.2011.00634 
Ghaderpanahi, L. (2012). Using authentic aural materials to develop listening comprehension in the EFL classroom. Canadian Center of Science and Education, 5, 146-153. doi:10.5539/elt.v5n6p146

Ghanbari, N., Esmaili, F., \& Rezam, M. (2015). The effect of using authentic materials on Iranian EFL Learners' vocabulary learning. Theory and Practice in Language Studies, 5, 2459-2468. doi: http://dx.doi.org/10.17507/tpls.0512.05

Kraiova, O. \& Tsybaniuk, T. (2015). Use of authentic video materials in teaching listening. Modern Information Technologies in The Sphere of Security and Defence, 3(24), 141-144. Retrieved from http://sit.nuou.org.ua/article/view/74451/71063

Laufer, B., \& Hulstijn, J. (2001). Incidental vocabulary acquisition in a second language: The construct of task-induced involvement. Applied linguistics, 22(1), 1-26.

Maxim, H. (2002). A study into the feasibility and effects of reading extended authentic discourse in the beginning German language classroom. The Modern Language Journal, 86(1), 20-35.

Martínez-Flor, A. (2007). Analyzing request modification devices in films: Implications for pragmatic learning in instructed foreign language contexts. In E. Alcón Soler \& M. P. Safont Jordà (Eds.), Intercultural language use and language learning (pp. 245279). Netherlands: Springer. Abstract retrieved from https://link.springer.com/chapter/10.1007\%2F978-1-4020-5639-0_13

Nation, I.S.P., (2001) Learning vocabulary in another language. Cambridge University Press: New York 
Ministerio de Educación Nacional. República de Colombia (2004). Estándares Básicos de Competencias Ciudadanas. Formar para la ciudadanía isí es posible! Lo que necesitamos saber y saber hacer. [Basic Standards of Citizenship Competences. Educating for citizenship is possible. What we need to know and know how to do]. Bogotá, Colombia.

Richards, J.C. (2001). Curriculum development in language teaching. Cambridge: Cambridge University Press.

Segueni, L. (2016). Developing learners communicative and pragmatic competence using authentic language data (Unpublished doctoral dissertation). Briska University, Nigeria.

UNESCO. 2014. Global Citizenship Education. Preparing Learners for the Challenges of the $21^{\text {st }}$ Century. Paris, UNESCO.

Zyzik, E. \& Polio, C. (2017). Authentic materials myths: Applying second language research to classroom teaching. Ann Arbor: University of Michigan Press. 


\section{Appendix A}

\section{Female Artist in Afghanistan}

\section{https://www.youtube.com/watch?v=TTRs3fhmYOQ}

\section{Discuss with a partner:}

Where is Afghanistan? $\rightarrow$ Sooth Asia

What do you know about Afghanistan?

2. Watch the video and answer. Check your answers with a partner

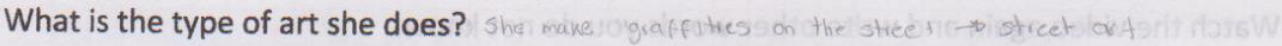
What kind of images does she paint? images that show reallity aboot her countre

How do men react when they see her painting on the street?

3. Watch the video again and answer. Check your answers with a partner.

why What is this artist's work important / unusual / special?

relations with music caose like that she show the power of them

that she needs to make hes art and almost 40 minuts. She promarale. a lot

What's the message she wants to transmit?

4. Check the list. Mark the words you do not know. Ask a classmate to help you and/or use a dictionary to find their meaning.
a. street art
b. murals
c. sketch $\rightarrow$ bos gogo
d. portraits $\rightarrow$ retratos
e. workshop $\rightarrow$ (grupo de estudio $)$ taller

\section{Use the words above to complete the following text:}

This woman risks her life to do street art in Afghanistan

Hassani sketches the beforehand

I'm trying to prepare everything before I go there, like the and my materials Hassani paints of women in hijabs and burqas

She started doing street art in 2010 at a graffiti

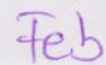


¿Le gusto el video? ¿Por qué?

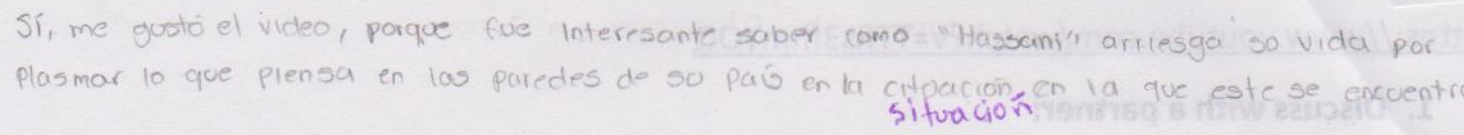

¿Qué dificultades tuvo durante la actividad con el video?

No pude entender laigunas palabra que aparecían en el vides, aidemas el videa sé seprodujo mog rópido g no alcance a leer todo por completo.

Watch the video again and write other words you do not know.

- beforhand
- awared
- sketch

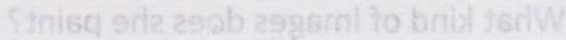

6. Choose and write the 6 words you WOULD LIKE TO LEARN from the previous list.

- sketch - despite.

- awared

- beford

7. HOMEWORK - For each word chosen:

a. write the type of word (noun, verb, adjective, adverb, etc)

b. write a definition or translation

c. Copy an example (from the dictionary) that contains the NEW WORD

d. Write 2 examples of your own that contain the NEW WORD 


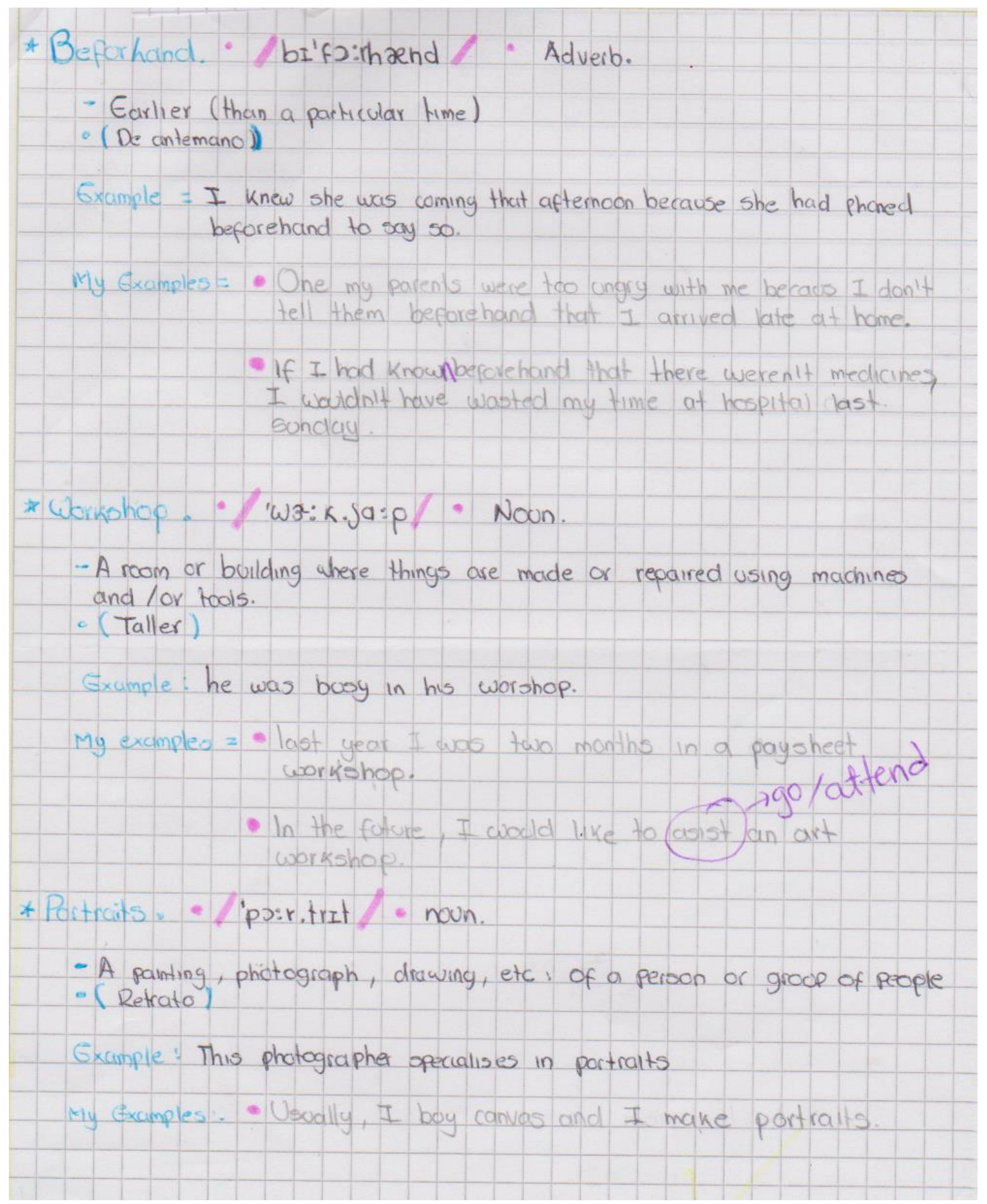




\section{Appendix B}

Video: Survival stories

https://www youtube.com/watch?vere97N245 pQ

Do you know any stories of survival from the news or people you know?

Match the story with the person
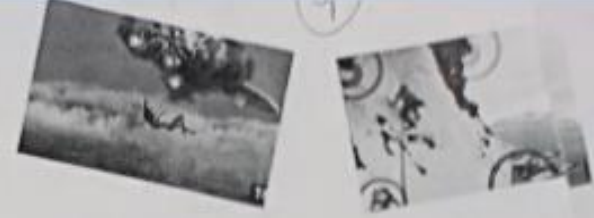

\begin{tabular}{|c|c|}
\hline $\begin{array}{l}\text { 10. The Donner party b. } \\
\text { 9 9. Hugh glass } \\
\text { e. Beck Weathers } 1996 \\
\text { C 7. Brad Cavanagh and Deborah } \\
\text { Scating Kiley } \\
\text { f 6. Phineas Gage } \\
\text { i } 5 \text {. Aaron Balston } \\
\text { a 4. José Salvador Alvarenga } \\
\text { d 3. Nando Parrado } \\
\text { h 2. Ernest Shackleton } \\
\text { 1. Vesna Vulovic }\end{array}$ & $\begin{array}{l}\text { a. Is a man who survived } 13 \text { months adrift in the Pacific Ocean. } \\
\text { b. was a group of people that were trapped during the winter. } \\
\text { (c) survived a bad weather shipwreck. } \\
\text { (d) survived a plane crash in the Andes. } \\
\text { (e) survived extreme conditions while walking down to his camp on mount } \\
\text { (d) survived an accident he had while he was rock-blasting for rail roads. } \\
\text { (b) was attacked by bear and deserted by the other men in the expedition. } \\
\text { (b. camped on the ice and then survived in the ocean. } \\
\text { (1.) survived after his right hand was crushed against a canyon wall. } \\
\text { (d) survived a } 33.000 \text { feet ( } 10058.4 \mathrm{~m} \text {.) fall after a plane crash. }\end{array}$ \\
\hline
\end{tabular}

Watch an excerpt from the beginning of the video. Then match the expression with the meaning.

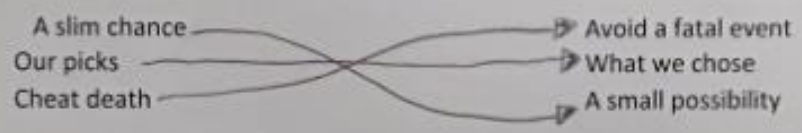

What story do you find the most amazing? Why? Aaron Batston. Becasse he had to deade belween survive or cut him arm, and he said. "I only thughis in hug my son again: in your opinion, what made these people survived? I thenk that they followed then survival instincs,

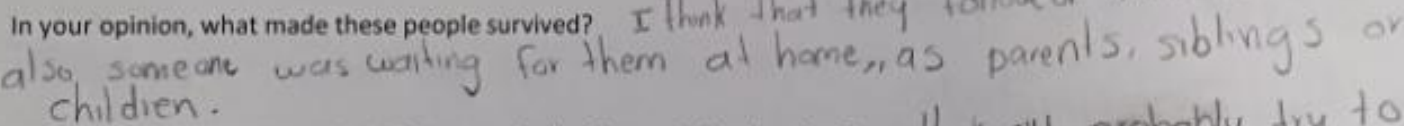

What do you think you would do if you ever had to face a similar situation? I think, j'll probably try to Suvive, but, I don't know. Maybe we don't know what things we will do when is? albout Survival.

What can you learn from thesestories? I learned from those videos, that even though everything seems lost, always we cautd have a small passibility.

always I cuill say i wont give up.

¿Qué te gustó del video? ¿Por qué? si, porque muestra como los peŕsonas logran sali.

Qué te gustó del video? ¿Por qué? si, porque muestra como los personas
de una situación que parece no tener salida. 4 lo más importante se
levantan con mas fuerza y ganas de 1 char. ¿Qué dificultades tuviste durante el desarrollo de las actividades sobre el video?

no entendi algunos terminos las codes escribi al final de esta guía.

¿Qué quieres aprender del video?

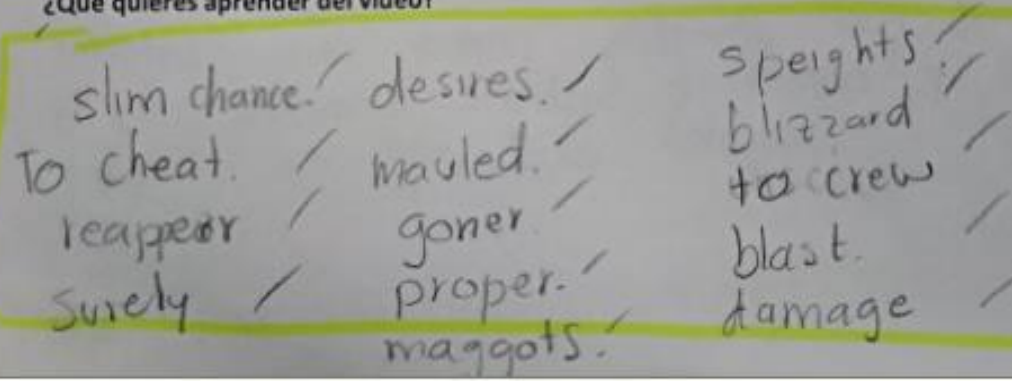

whereabouts 


\section{Appendix C}

FORM A

1. Watch the video: https://www.youtube.com/watch?v=cDAlrwGLDdk

2. Answer the following questions in pairs: Where is it located? What is it called? What is especial about it? Have you been there?

3. Check the following phrases in the box. Use a dictionary to look up the meaning of unknown vocabulary. Write the pronunciation of the words. Write the type of word (noun, adj, verb, adverb). Write one example of your own for each phrase.

A liquid rainbow

- Green mosses

- A natural spectacle

- It is as stunning as it is inaccessible

_ Prehistoric black rocks

My own examples:

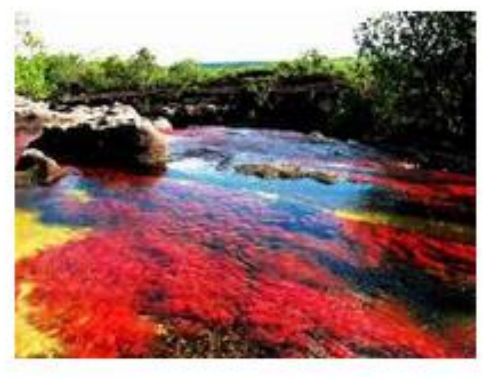

4. Watch the video again, pay attention to the vocabulary in the box. Write the phrases (from the box) in the order they are mentioned in the video. Listen again, confirm.

1.

2.

3.

4.

5. 
5. Work in pairs $(A+B)$, share your vocabulary lists, explain vocabulary to one another. TAKE NOTES on the vocabulary your classmate explained to you. Talk to your teacher if you have any questions/comments/ doubts.

6. Discuss with your partner. Would you like to go there? Why?

7. Describe the rainbow river according to the video.

8. Did you like the video? Why?

9. What difficulties did you have during the activity? 
1. Watch the video: https://www.youtube.com/watch?v=cDAlrwGLDdk

2. Answer the following questions in pairs: Where is it located? What is it called? What is especial about it? Have you been there?

/

3. Check the following phrases in the box. Use a dictionary to look up the meaning of unknown vocabulary. Write the pronunciation of the word. Write the type of word (noun, adj, verb, adverb). Write 1 example of your own for each phrase.

A dazzling array of colors

mesmerizing pools, water falls, rapids and caves

Vivid yellow sands

Unique kaleidoscope

Pure blue waters

My own Examples:

4. Watch the video again, pay attention to the vocabulary in the box. Write the phrases (from the box) in the order they are mentioned in the video. Listen again, confirm.

1.

2.

3.

4.

5.

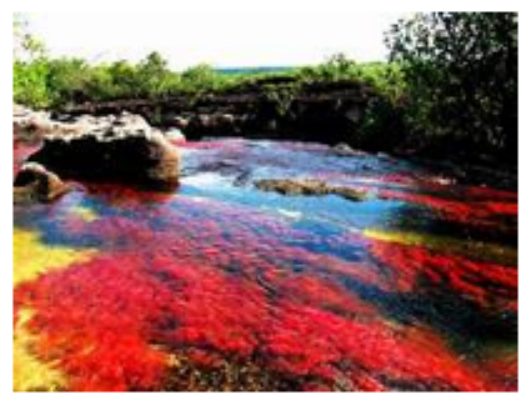


5. Work in pairs $(A+B)$, share your vocabulary lists, explain vocabulary to one another. TAKE NOTES on the vocabulary your classmate explained to you. Talk to your teacher if you have any questions/comments/ doubts.

6. Discuss with your partner. Would you like to go there? Why?

7. Describe the rainbow river according to the video.

8. Did you like the video? Why?

9. What difficulties did you have during the activity? 